\title{
Correction to: Intrapandemic regional anesthesia as practice: a historical cohort study in patients undergoing breast cancer surgery
}

\section{Correction à : $L$ 'anesthésie régionale en tant que pratique intrapandémique : une étude de cohorte historique chez des patientes bénéficiant d'une chirurgie de cancer du sein}

\author{
Ariane Clairoux, MD, FRCPC (D) - Maxim Soucy-Proulx, MD • François Pretto, MD • \\ Victoria Courgeon, MD • Maxime Caron-Goudreau, MD • Rami Issa, MD, Beng, FRCPC • \\ Marie-Ève Bélanger, MD, PGdip(ed), FRCPC • Véronique Brulotte, MD, MSc, FRCPC • \\ Olivier Verdonck, MD, MSc, DESAR • Moulay Idrissi, BEng, MSc • Annik Fortier, MSc • \\ Philippe Richebé, MD, PhD, DESAR
}

Published online: 4 March 2022

(C) Canadian Anesthesiologists' Society 2022

Correction to:

Canadian Journal of Anesthesia/Journal canadien d'anesthésie

https://doi.org/10.1007/s12630-021-02182-0

This article was updated to correct the display of negative numbers in the tables.

The original article can be found online at https://doi.org/10.1007/ s12630-021-02182-0.

A. Clairoux, MD, FRCPC $(\bowtie) \cdot R$. Issa, MD, Beng, FRCPC Marie-ÈveBélanger, MD, PGdip(ed), FRCPC · V. Brulotte, MD, MSc, FRCPC · O. Verdonck, MD, MSc, DESAR - M. Idrissi,

BEng, MSc · P. Richebé, MD, PhD, DESAR

Department of Anesthesiology and Pain Medicine,

Maisonneuve-Rosemont Hospital, CIUSSS de l'Est de l'Ile de

Montréal (CEMTL), University of Montreal, 5415, Boulevard de

l'Assomption, Montreal, QC H1T 2M4, Canada

e-mail: ariane.clairoux@umontreal.ca

Department of Anesthesiology and Pain Medicine, University of Montreal, Montreal, QC, Canada

M. Soucy-Proulx, MD - F. Pretto, MD - V. Courgeon, MD .

M. Caron-Goudreau, MD

Department of Anesthesiology and Pain Medicine, University of

Montreal, Montreal, QC, Canada

\section{A. Fortier, MSc}

Department of Statistics, Montreal Health Innovations

Coordinating Center (MHICC), Montreal, QC, Canada
Publisher's Note Springer Nature remains neutral with regard to jurisdictional claims in published maps and institutional affiliations. 